\title{
Metasomatic alteration of chromian- spinels in an Archean ultramafic section, southern India and its implications
}

\author{
P M GEORGE ${ }^{1}$ AND MING GUO ZHAI ${ }^{2}$ \\ ${ }^{1}$ Northwest University \\ ${ }^{2}$ Institute of Geology and Geophysics, Chinese Academy of \\ Sciences \\ Presenting Author: gpmaths@nwu.edu.cn
}

Metasomatic alteration of chromian-spinels in an Archean ultramafic section, southern India and its implications

Cr-spinel $\left(\left(\mathrm{Mg}, \mathrm{Fe}^{+2}\right) \quad\left(\mathrm{Cr}, \mathrm{A} 1, \quad \mathrm{Fe}^{+3}\right)_{2} \mathrm{O}_{4}\right)$ chemistry is extensively used as a petrogenetic indicator of mafic-ultramafic rocks [1]. In this study, the Cr-spinel chemistry of a metasomatized ultramafic section within Mesoarchean Sargur group[2] of Western Dharwar Craton, southern India, was investigated. The segment comprises of intercalated occurrences komatiite, serpentinite and amphibolite, which are cut-across extensively by magnesite veins. Chromian-spinels were found only to occur in the komatiite and serpentinite, within the matrix, as accessory minerals with their sizes ranging from $400 \mu \mathrm{m}$ $1 \mathrm{~mm}$, having no or weak compositional zoning. The Cr-spinels in the serpentinite have high $\mathrm{Cr}_{2} \mathrm{O}_{3}$ content (43.8-49.75 wt \%), low $\mathrm{Al}_{2} \mathrm{O}_{3}(5.9-10.4 \mathrm{wt} \%)$ and their $\mathrm{Cr} \#(\mathrm{Cr} /(\mathrm{Cr}+\mathrm{Al}))$ values ranging between $0.75-0.85$. However, the spinels in the komatiite have very high $\mathrm{FeO}$ content (82-91 wt \%), very low $\mathrm{Cr}$ (5.7- 10.4 wt $\%)$ and $\mathrm{Al}_{2} \mathrm{O}_{3}$ content $(0.05-0.39 \mathrm{wt} \%)$, which indicates they are ferrit-chromite $\left(\mathrm{Fe}^{2+} / \mathrm{Fe}^{3+}=0.99-1.01\right)$ or magnetite. It is therefore obvious that the $\mathrm{Cr}$-spinels in the komatiite are highly altered, probably due to the impact of fluid infiltration from the magnesite veins. The composition of the $\mathrm{Cr}$-spinel from the serpentinite falls in to the subduction fields of various conventional discrimination diagrams used to distinguish the original setting of the $\mathrm{Cr}$-spinels. In this given scenario, there lies a pit-fall that the composition of Cr-spinel in the serpentinite are most likely to be interpreted as the ones that preserved their original composition, by overlooking the fact that the rock is serpentinized. A recent study [3] however cautions that late fluids tend to alter the $\mathrm{Cr} / \mathrm{Al}$ values of the $\mathrm{Cr}$-spinel and is rather a potential sink for fluid-mobile elements. Therefore, it can be concluded that the $\mathrm{Cr}$-spinel in the serpentinite are not pristine, but are also altered products and therefore makes it a good proxy to understand the metasomatic processes.

\section{References}

[1]Irvine (1965), Can. J. Earth Sci. 4, 71-103. [2] Jayananda et al. (2018), Earth Sci.Rev.181, 12-42. [3] Gamal El Dien et al. (2019), Nat. Commun. 10, 5103. 